\title{
Structural Style in the Zagros Fold-Thrust Belt: The Gavbast Anticline, Coastal Fars
}

\author{
Hadi Vaseghi, Zahra Maleki*, Mehran Arian \\ Department of Geology, Science and Research Branch, Islamic Azad University, Tehran, Iran \\ Email: ${ }^{2}$ z.maleki@srbiau.ac.ir
}

Received 22 October 2015; accepted 26 February 2016; published 29 February 2016

Copyright (C) 2016 by authors and Scientific Research Publishing Inc.

This work is licensed under the Creative Commons Attribution International License (CC BY). http://creativecommons.org/licenses/by/4.0/

(c) (7) Open Access

\begin{abstract}
The Gavbast anticline is located in the Coastal Fars area of the Zagros folded belt, with north-south trend. The study anticline is restricted to the Bavush and Paskhand anticlines from North, the Gezzeh and Dehnow anticlines from South, the Varavi anticline from West and Nakh anticline from East (Figure 1). Description of fold geometry is important because they allow comparisons within and between folds and pattern-recognition in addition to occurrence and distribution of fold systems. The main goal of this paper is to define folding style of the Gavbast anticline and define structural features affected on them in the study area. In this research, we used the Tectonics FP software, Global Mapper software and geological maps and reports of Iranian National Oil Company. In addition, we used common classification of fold for indicating of folding mechanism of the Tabnak anticlinal structure. In the Gavbast anticline, fold style elements in all parts of this anticline have been calculated and analyzed for indicating of folding style mechanism. The results of this method have been shown the folding geometry changes accurately. The Gavbast anticline is gentle in structural sections D-D' and G-G' to K-K'. The anticline is an open fold in the L-L' section. Also fold type in the E-E' and F-F' sections of the Gavbast anticline is steeply inclined sub-horizontal. These sections are located between the Razak (western part) and Hendurabi fault (eastern part). It seems that E-E' and F-F' parts in the Gavbast anticline have been suffered most deformation affected by the Razak and Hendurabi faults. At the end of, it seems that, the Razak and Hendurabi faults have major effects on folding style. This structure is a very good sample for effect of strike slip faults on the folding geometry and for this reason; the Gavbast anticline is considered a special structural style in the Zagros fold-thrust Belt.
\end{abstract}

\section{Keywords}

Zagros, Iran, Gavbast Anticline, Fold Geometry, Razak Fault, Hendurabi Fault

${ }^{*}$ Corresponding author. 


\section{Introduction}

The dominant structures in the Zagros fold-thrust belt are folds and thrusts with northwestern-southeastern trend. This structure has main tendency toward southwestern. Based on morphology view, this belt is divided to High Zagros and Folded Zagros. The average height of this belt is near to 1200 meters. According to structural classification, the Zagros fold-thrust belt from northeastern to southeastern is divided to High Zagros Thrust Belt, Simply Folded Belt, Zagros Foredeep and Coastal Plane [1]. This belt based on facies changes from northwestern to southeastern is divided to Lurestan basin (northwestern of Zagros), Khuzestan basin (Central Zagros) and Fars basin (southeastern of Zagros). The study area is located in the Coastal Fars sub-basin.

The Zagros fold-thrust belt develops principally consequent of folding and thrusting of the Cenozoic foreland sequence. This sedimentary sequence deformed has been underlaid during Paleozoic-Mesozoic and mainly belongs to deposits of the Arabian plate and margin. In the Zagros, the northward motion of Arabian plate related to the Eurasia plate has caused the active deformation. The Zagros belt is divided into several geological zones that are different based on their sedimentary history, stratigraphy facies and structural style [2]-[4]. The majority of Iran's reservoirs are located in the Zagros Folded Belt and the Persian Gulf basin. Because enormous gas reserves exist in the Permo-Triassic carbonate reservoirs of the Zagros Folded Belt, anticlines in this belt have the major significance from hydrocarbon traps reservoirs, especially in the Fars area. For this reason, investigation of oil traps of the oil-rich areas is very important to analyze the factors influencing the evolution and geometry of the anticlinal structures Zagros foreland area, specially the folding mechanism analysis.

The Gavbast anticline, with north-south trend is located in the Coastal Fars area of the Zagros folded belt. The study anticline is restricted to the Bavush and Paskhand anticlines from north, the Gezzeh and Dehnow anticlines from South, the Varavi anticline from West and Nakh anticline from east (Figure 1). These anticlines are

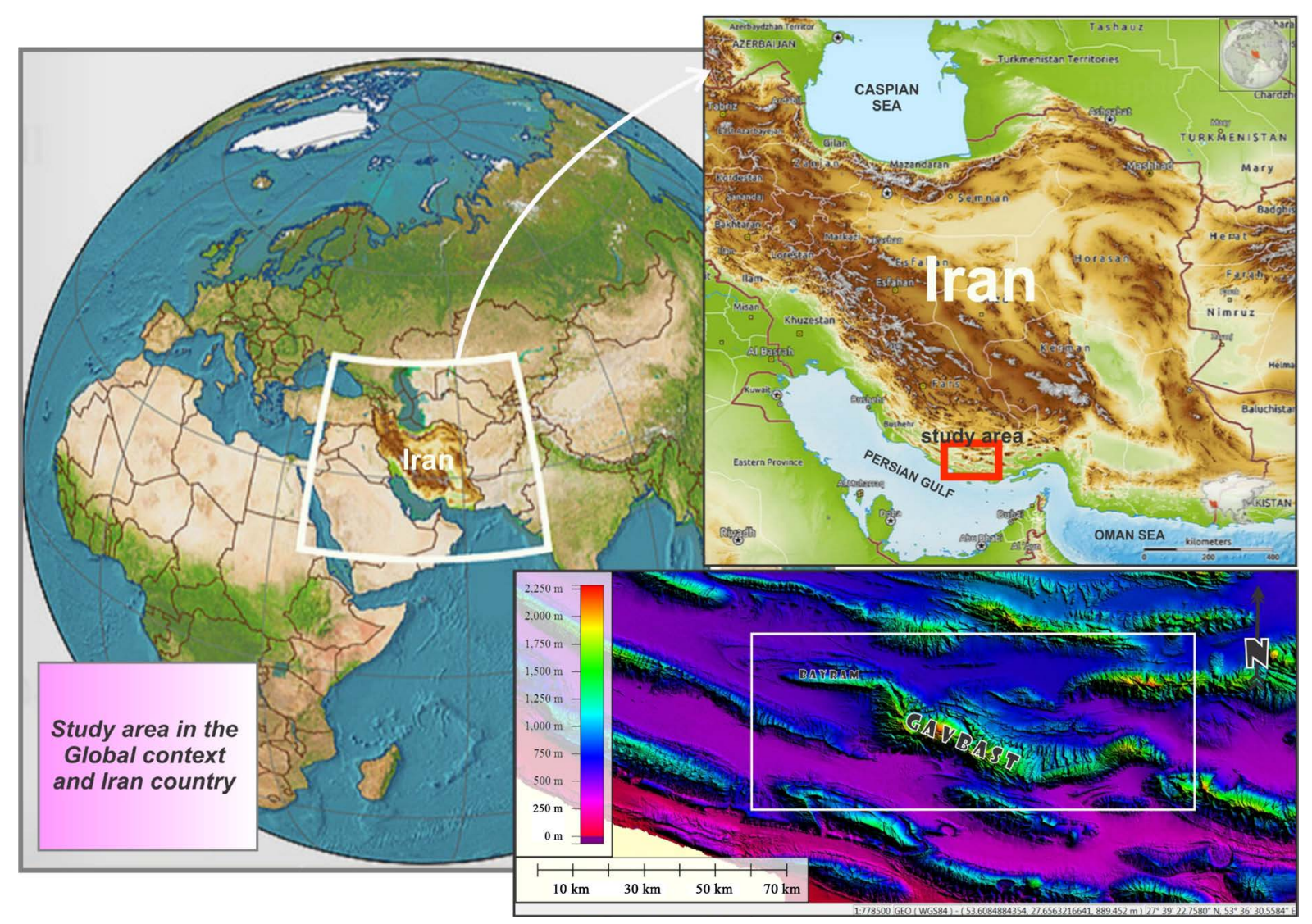

Figure 1. Landsat Satellite image shows the study area and location of the Gavbast anticline in the Zagros fold-thrust belt, southern of Iran. Inset Satellite image (a) shows location of the study area with white framework in the Middle East. Also, in this figure shows location of the Gavbast salt plug in the study area. 
located along the general trend of Zagros folded belt. The study area is located in the southern part of the Zagros folded belt and geology of the Fars province. Base on theological characteristics, the Fars province is divided based on stratigraphic facies characteristics, sedimentary and geological environment into two parts the Interior Fars and Exterior Fars. Accordingly, the Exterior Fars is divided into two sub-Coastal Fars and Coastal Fars sub-zones [4]. The Razak and Hendurabi faults are the main faults in the study area. These faults are located in East and another one in west of the Gavbast anticline. This anticline has been affected by these faults. It seems that, the separator factor of the anticline that caused the Bayram anticline has been divided from the Gavbast anticline is the $\mathrm{R}$ fault. This fault is considered as Eastern boundary from the Gavbandi Paleo-High [5] (Figure 2). The Fars area has been a platform, and this area has been suffered repeated uplift during the Mesozoic. The Paleo-High Gavbandi [4] has been affected on this area.

Based on obtained information from seismic reflection profiles and hydrocarbon exploration wells, the sedimentary cover has important detachment units between competent units in different parts of the Zagros Fold Belt. These detachment units have been controlled on the geometry and the folding style. The main detachment units in this belt are Dashtak, Gachsaran formations. For instance important detachment units around the Zagros folded belt are lower Paleozoic shales. Also in the Coastal Fars sub-basins, Dashtak Formation is the most important middle level detachment units. Description of fold geometry is important because they allow comparisons within and between folds and pattern-recognition in addition to occurrence and distribution of fold systems. The main goal of this paper is to define of folding style of the Gavbast anticline and define structural features affected on them in the study area.

\section{Material and Methods}

This paper presents part of the results of a regional study of the Coastal Fars area in the Zagros Simply folded belt, based on original fieldwork, satellite images, structural sections, geological maps and well data. We used fold style elements analysis methods (description of folds) based on [6]-[9]. We used Tectonics FP software for prepared and analyzed Stereoplots of the Gavbastanticline. In addition, we used Global Mapper Software forprepared 3D SRTM of the study area and 3D Path Profile (along cross sections) based on Global Mapper Software. The SRTM images prepared based on Digital Elevation Model (DEM) and geological map of study area (published by the National Oil Company and the Geological Survey of Iran).

\section{Geological Setting and Stratigraphy}

The Zagros orogeny belt has northwest-southeast trend and this belt is located from Anatolian eastern fault to Oman lineament in south of Iran. This belt as fold-thrust belt is bounded from north boundary by Iran plate and

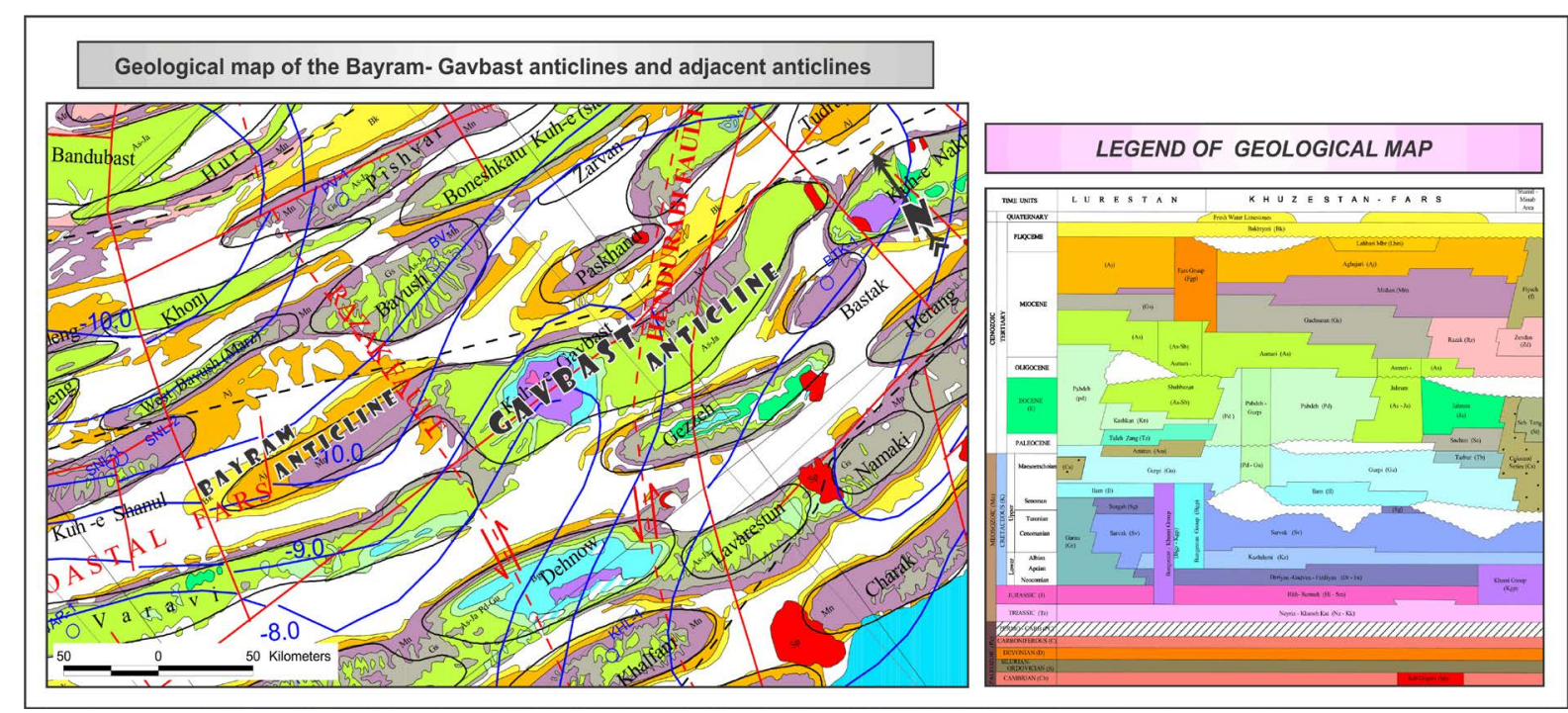

Figure 2. Geological map of the Gavbast anticline. In this map shows the position of salt plug that exposed in the middle part of anticline. Modified after [11]. 
from south boundary by north eastern edge of Arabian plate. The Zagros orogenic belt has been formed by convergent continental-continental plates of the Iran and Arabia-Africa in upper cretaceous that continuous to present day. This convergent has caused close the Neotethys. The Zagros orogenic belt has $200-300 \mathrm{~km}$ width and this belt is located along with other parts of the Zagros belt from Anatolian eastern part toward Oman line in south of Iran [10]. The Zagros fold-thrust belt includes amazing whaleback anticlines that are excellently outcropped in Tertiary and Mesozoic limestone. These anticlines generally have $4100 \mathrm{~km}$ length and large proportion of the worldwide hydrocarbon reserves. According geomorphological and structural features, the Zagros belt consists of two Subzones (i.e., Thrust Subzone and Folded Zagros Subzone). The Folded Zagros Subzone has been subdivided into seven parts based on geology specifications, including Lurestan, Khuzestan, Abadan plain, Fars, Bandar Abbas and salt structures with metamorphic rocks [3]. The numerous of folds trend are parallel with northwest-southeast tend that this trend formed as a result of the Arabian-Iranian plate collision. These anticlines have been same characteristics such as high amplitude and mountain apex with height between 3000 and 3650 meter above sea level.

In the study area, main strike-slip faults are Razak and Hendurabi faults with sinistral displacement (Figure 1). May be, these faults have an effects on the geometry of the folds in the study area. The drilling well near by the Gavbast anticline is located in the Bastak anticline in the south of the study anticline. The oldest stratigraphic unit in the study anticline is the Hormuz Series and the effects of this oldest stratigraphic unit as a buried salt dome in the middle of the anticline, and salt domes outcropping in the eastern part. The Gavbast anticline has the complex asymmetric structure and highest point about 2170 meters. This structure has been main geometric variations in eastern and western parts in to middle part that is clearly visible on the satellite image (Figure 1). The Gavbast anticline is a huge anticline with dip of northern flank greater than southern flank totally. In this anticline, in places where has been eroded the Asmari formations, the Pabdeh and Gurpi are exposed. The width of this structure in the middle part more than eastern and western parts (Bayram anticline). This structure has been main geometric variations in eastern and western compared to middle part (Figure 1, Figure 2).

The Gavbast anticline is situated in the Simply Folded Belt of the Zagros orogeny and in the Bastak area. The structural and stratigraphic characteristics have been described in detail by [2]-[4] in the Zagros sedimentary sequence. The geological formations cropping out in this anticline (respectively from oldest to newest) are the Hormuz salt (Precambrian-Middle Cambrian), Surmeh limestone and dolomite (Jurassic), Khami limestone (Jurassic-Lower Cretaceous), Sarvak limestone (Cretaceous), Pabdeh-Gurpi shale and marl (Cretaceous-Tertiary), Asmari limestone (Oligo-Miocene), Gachsaran marl and evaporites (Tertiary), Mishan marl and shale (Tertiary), Aghajari sandstone and marlstone (Tertiary) and Bakhtiari conglomerate (Quaternary). The karstic Asmari Formation is the main formation cropping out in the Gavbast Anticline and two older (Jurassic to Lower Cretaceous) carbonate formations of the Surmeh and Khami are exposed in the same dome cropping out in the core of the Gavbast anticline in its central part (Figure 2). These formations are not outcropped in the adjacent anticlines.

\section{Results and Discussion}

The Bayram-Gavbast anticline or Gavbast anticline in general is located in the Zagros fold-thrust belt and Coastal Fars sub-basin. The Bayram anticlinal part is located on the region known as the Gavbandi Paleo-High or Fars High on which evaporites layers have been generally absent or thin [12] [13]. In this region, the surface geometry of folds above the Gavbandi Palo-High varies significantly from that of those formed to the side of this uplift and the anticlines along with the edge of this high have narrow shape compared to adjacent area. This is can be clearly seen on the geological map or satellite images (Figures 1-3). For accurate analysis and interpretation in the study area, we used fold style elements analysis.

Based on [7] for description of fold, seven stereoplots (output of Tectonics FP software) were prepared for seven parts of the Gavbast anticline. According to results, these stereoplots show the location of axial plane (AP) and cylindricity (AC) and Plunge of Fold (P) (Figure 4). This part to be done based on seven structural cross sections of the Gavbast anticline. The locations of these structural cross sections (from A-A' to G-G') is shown in Figure 3, Figure 4.

As in Figure 4 can be seen, the A to L letters represent the location of the fold sections base on structural sections A-A' to L-L' in the study anticline. Based on the classification of the [9], the type of folds and geometry of the axial surface (AP) in the study anticline have been indicated changes in different part of the fold. Based on 


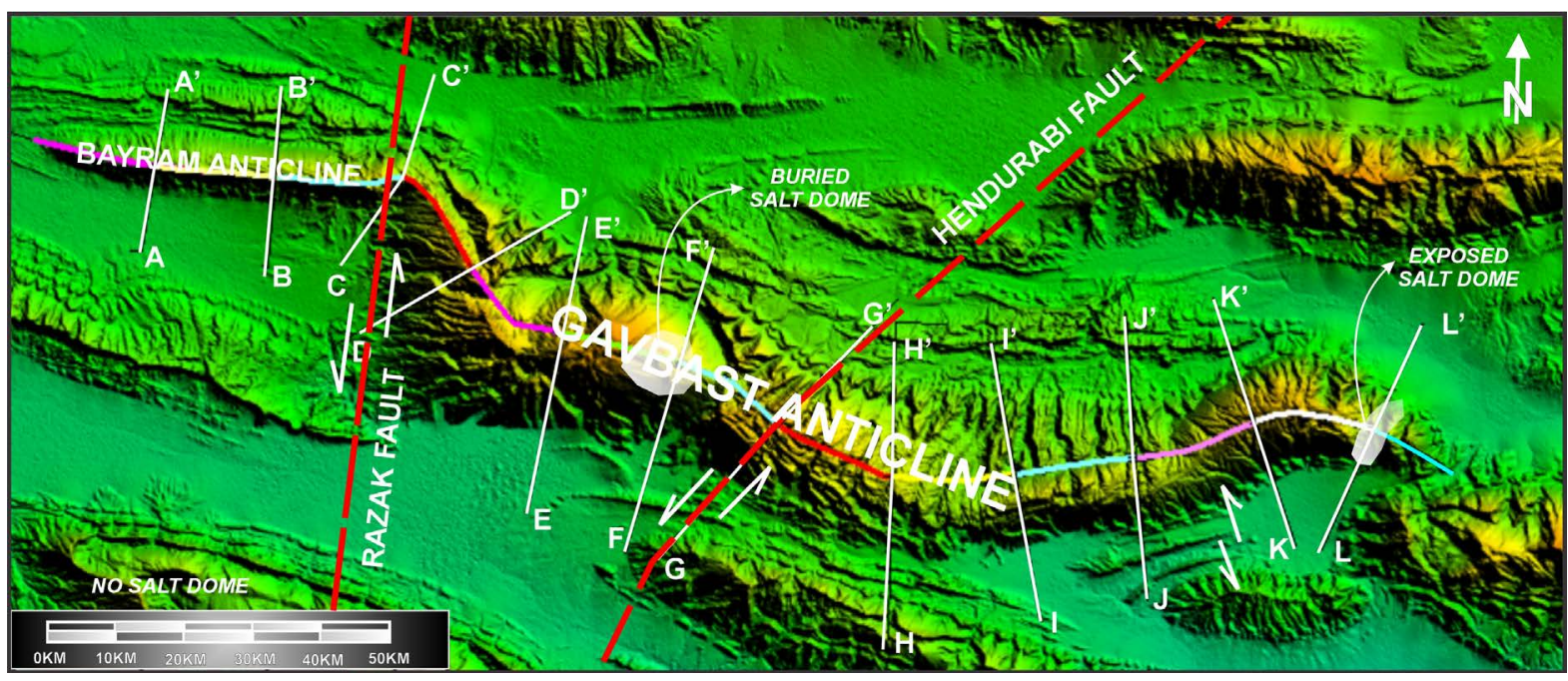

Figure 3. Location of the studied structural sections in the Bayram-Gavbast anticline.

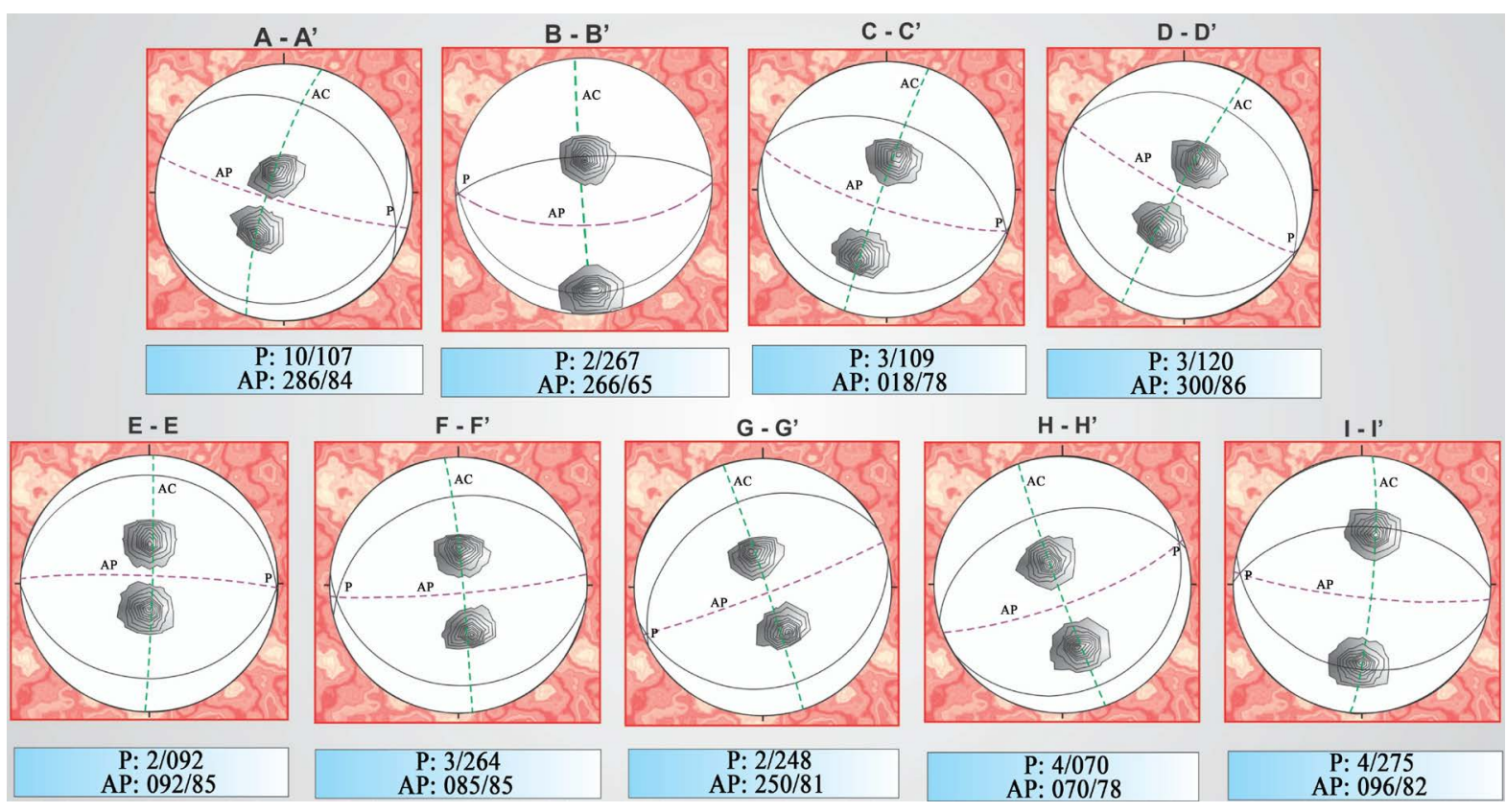

Figure 4. Stereoplots show axial planes (AP), cylindricity (AC) and plunge of fold (P) for seven sections of the Gavbast anticline.

the classification [7], type of the fold is open accordance with the structural section A-A' and C-C' (Bayram anticline). In addition, based on this classification, type of fold is gentle in the Gavbast anticline, in the structural sections D-D' and G-G' to K-K'. The type of fold is in the L-L' section is open.

It should be noted the structural sections accordance with A-A' and B-B' sections are located in the Bayram anticline and on the Gavbandi Paleo-High, Also E-E' and F-F' sections are located in the Gavbast anticline. These two sections are located between two faults as the Razak fault (western Division) and Hendurabi fault (eastern part). This means that, between B-B' and C-C' its located the Razak fault and this fault has been affected on the fold type. Also, the Hendurabi fault has been affected on the fold type especially on the between the E-E' and F-F' sections. It is remarkable that type of fold based on [8] classification is "steeply inclined sub horizontal". This case can indicate that the Razak fault and Hendurabi fault as sinistral strike slip faults [14]-[18] have been affected on the fold type. When the effective stress and deformation value is different, the type of fold has been changed in different parts of fold. This case may be created by cropping out of the salt domes, activi- 
ties of main active faults and other structural elements. The study anticline is a good example or special structural feature in the Zagros fold-thrust belt that is shown the effects of the strike slip faults on the folding geometry.

At finally, due to its position on top of anticline Bayram old Gavbandi and thinner series of Hormuz as the main separation unit thickness greater than that of the anticline the Gavbast different wavelengths of fold and folding geometry of these structures with each other. It seems, in fact, an anticline Bayram-Gavbst is due to the fault of Razak and Hendurabi is fold different wavelength and the geometry of the folds.

In this part, based on classification [6]-[9] in different parts of the Gavbast anticline, type of fold is variable and four types are recognized. In Figure 5, 3D path profiles show that location of these profiles is match along the cross sections in the study area.

Our results compatible with on previous work on the neotectonic regime in Iran [19]-[21] which it is implying Zagros in south Iran is the most active zone [22]-[32]. Then, Alborz [33]-[38] and Central Iran [39]-[45] have been situated in the next orders. From neotectonics point of view, the study area has formed on the northeastern part of Arabian plate's passive margin [46].

\section{Conclusions}

In the Gavbast anticline, fold style elements in all parts of this anticline have been calculated and analyzed for indicating folding style mechanism. The results of this method have been shown the folding geometry changes accurately. The Gavbast anticline is gentle in structural sections D-D' and G-G' to K-K'. The anticline is an open fold in the L-L' section. Also fold in the E-E' and F-F' sections of the Gavbast anticline is steeply inclined sub-horizontal. These sections are located between the Razak (western part) and Hendurabi fault (eastern part). It seems that E-E' and F-F' parts in the Gavbast anticline have been suffered most deformation affected by the Razak and Hendurabi faults.

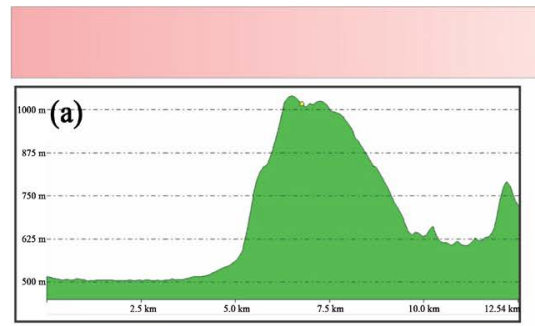

\section{Bayram Anticline}
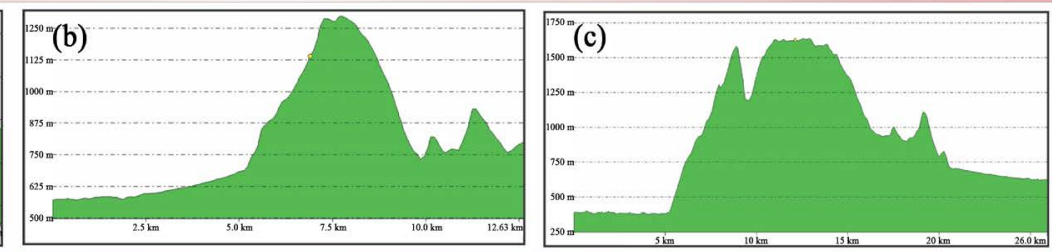

\section{Gavbast Anticline}
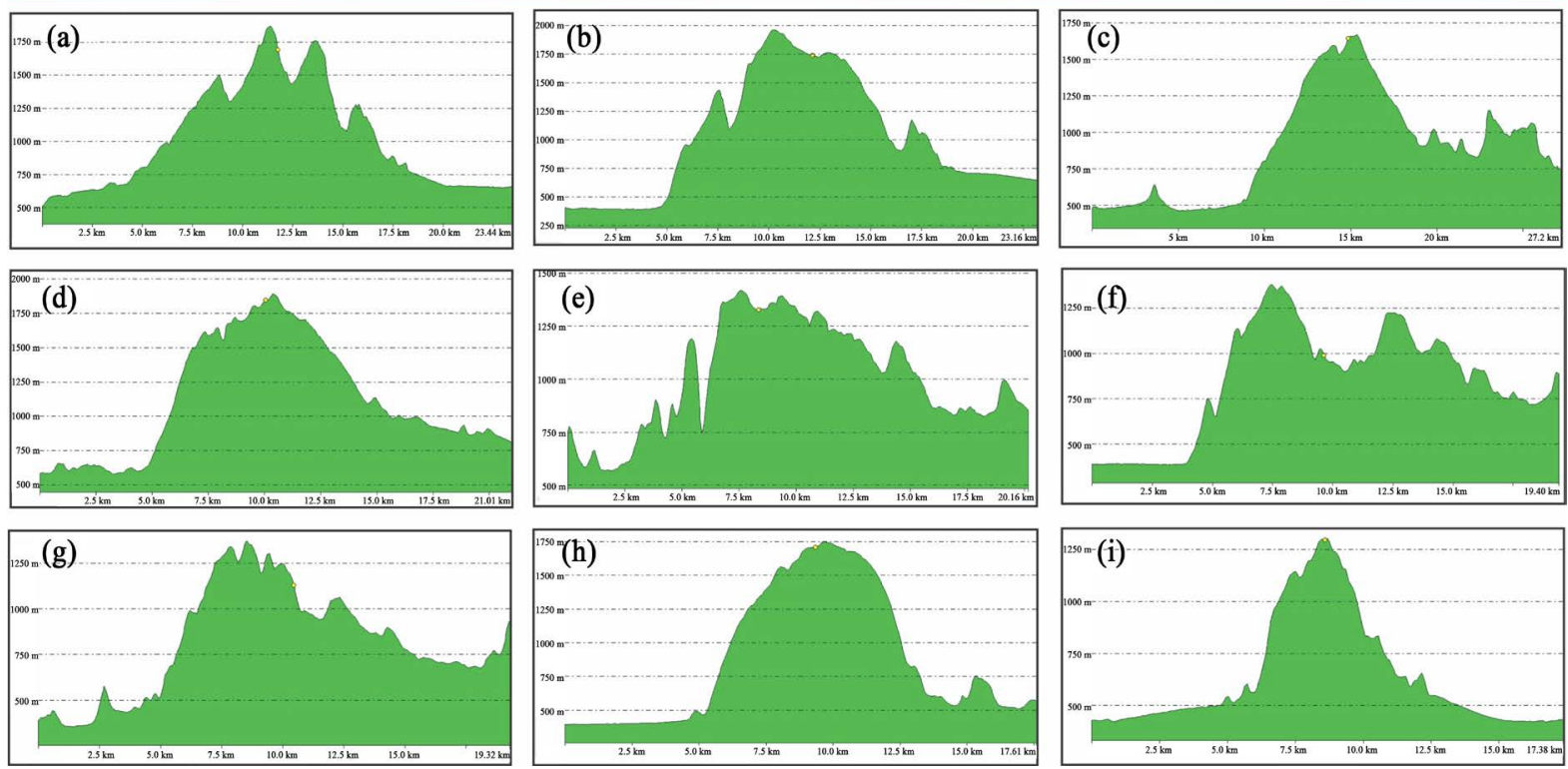

Figure 5. Cross sections across the Gavbast anticline. Lines of section as indicated in Figure 2 (Zarei, 2013). 
Finally, it seems that, the Razak and Hendurabi faults have major effects on folding style base on changes of the folding geometry. For more analysis, when the effective stress and deformation value are different, the type of fold has been changed in different parts of fold. This case may be created by cropping out of the salt domes, activities of main active faults and other structural elements. The study anticline is a good example or special structural feature in the Zagros fold-thrust belt that is shown the effects of the strike slip faults on the folding geometry.

\section{Acknowledgements}

The author acknowledges the Department of Geology, Islamic Azad University, Science and Research Branch, Tehran, Iran for funded this project. In addition, we thank Vice-President for Research in Science and Research branch, Tehran.

\section{References}

[1] Alavi, M. (2007) Structures of the Zagros Fold-Thrust Belt in Iran. American Journal of Science, 307, 1064-1095. http://dx.doi.org/10.2475/09.2007.02

[2] Falcon, N.L. (1974) Southern Iran: Zagros Mountains. Vol. 4, Special Publications, Geological Society, London, 199211. http://dx.doi.org/10.1144/GSL.SP.2005.004.01.11

[3] Aghanabati, S.A. (2004) Geology of Iran. Geological Survey of Iran 2004, 586.

[4] Motiei, H. (1993) Stratigraphy of Zagros. Treatise on the Geology of Iran. Ministry of Mines and Metals, Geological Survey of Iran, Tehran.

[5] Setudehnia, A. and Perry, J.T. (1965) Geological Map of SE \& SE Fars, Scale 1: 250,000. National Iranian Oil Company, Tehran.

[6] Ragan, D.M. (1985) Structural Geology, an Introduction to Geometrical Techniques. 3rd Edition, John Wiley \& Sons, Inc., New York, 210-215.

[7] Twiss, R.J. and. Moores, E.M. (1992) Structural Geology. W.H. Freeman and Company, New York, 532.

[8] Ramsay, J.G. (1967) Folding and Fracturing of Rocks. McGraw-Hill, New York, 568.

[9] Rickard, M.J. (1971) A Classification Diagram for Fold Orientation, Geological Magazine, 108, 23-26. http://dx.doi.org/10.1017/S0016756800050925

[10] Alavi, M. (2004) Regional Stratigraphy of the Zagros Fold-Thrust Belt of Iran and Its Proforeland Evolution. American Journal of Science, 304, 1-20. http://dx.doi.org/10.2475/ajs.304.1.1

[11] NIOC (2001) Geological Map of the Zagros, Iran. National Iranian Oil Company, Tehran.

[12] Beydoun, Z.R., Hughes Clark, M.W. and Stoneley, R. (1992) Petroleum in the Zagros Basin: A Late Tertiary Foreland Basin Overprinted onto the Outer Edge of a Vast Hydrocarbon-Rich Palaeozoic-Mesozoic Passive Margin Shelf. In: Macqueen, R. and Leckie, D., Eds., Foreland Basins and Foldbelts, American Association of Petroleum Geologists, Tulsa, 309-339.

[13] Talbot, C.J. and Alavi, M. (1996) The Past of a Future Syntaxis across the Zagros. In: Alsop, G.I., Blundell, D.J. and Davison, I., Eds., Salt Tectonics, Geological Society of London, London, 89-109. http://dx.doi.org/10.1144/gsl.sp.1996.100.01.08

[14] Hessami, K. (2001) The Significance of Strike-Slip Faulting in the Basement of the Zagros Sold and Thrust Belt. Journal of Petroleum Geology, 24, 5-28.

[15] Ghanavati, D. (2009) Geometry of Folding Style Analysis in the Coastal Fars and Effects of Nezamabad Fault in the Structures Region. PhD Thesis of Structural Geology, Islamic Azad University, Science and Research Branch, Tehran, 200.

[16] Barzegar, F. (1992) Introducing Firuzabad and Nezamabad Faults. Proceedings of the 10th Geosciences Conference, Tehran, 2-4 February, 15-16.

[17] Furst, M. (1990) Strike-Slip Faults and Diapirism of the South-Eastern Zagros Ranges. Proceeding of Symposium on Diapirism, 2, 149-182.

[18] Nogole-Sadat, M.A.A. and Almasian, M. (1993) Tectonic Map of Iran, Scale 1:1000, 000. Geological Survey of Iran, Tehran.

[19] Qorashi, M. and Arian, M. (2011) Tectonics of Iran. Geologic Survey of Iran, Tehran, 336 p.

[20] Arian, M. (2011) Basement Tectonics and Geology of Iran. Asar Nafis Press, Qum, 300 p.

[21] Arian, M. (2011) A Preface on Salt Diapirism of Iran. Asar Nafis Press, Qum, 309 p. 
[22] Arian, M. and Aram, Z. (2014) Relative Tectonic Activity Classification in the Kermanshah Area, Western Iran. Solid Earth, 5, 1277-1291. http://dx.doi.org/10.5194/se-5-1277-2014

[23] Pazhoohan, M., Arian, M., Ghorashi, M. and Khosrotehrani, K. (2014) A Study of Drainage Pattern Responses to Active Tectonics in Tadvan Region, SW Iran. Geodynamics, 1, 36-41.

[24] Rahimi, N. and Arian, M. (2014) Tectonic Geomorphplogy of Hamedan-Sosangerd Region, West Iran. Advances in Environmental Biology, 8, 119-124.

[25] Maleki, Z., Arian, M., Solgi, A. and Ganjavian, M.A. (2014) The Elements of Fold Style Analysis in the Khaftar Anticline, Zagros, Iran. Open Journal of Geology, 4, 79-92. http://dx.doi.org/10.4236/ojg.2014.43008

[26] Maleki, Z., Arian, M. and Solgi, A. (2014) Structural Style and Hydrocarbon Trap of Karbasi Anticline, in the Interior Fars Region, Zagros, Iran. Solid Earth Discussions, 6, 2143-2167. http://dx.doi.org/10.5194/sed-6-2143-2014

[27] Ehsani, J., Arian, M. and Ghorashi, M. (2015) Geomorphic Signatures of Active Tectonics in the Jarahi-Hendijan Drainage Basin in the South West Iran. Geosciences, 24, 211-218.

[28] Khodabakhshnezhad, A., Pourkermani, M., Arian, M., Matkan, A.A. and Charchi, A. (2015) Active Tectonics of Great Karoun River Basin. Geosciences, 24, 13-28.

[29] Maleki, Z., Arian, M., Solgi, A. and Ganjavian, M.A. (2015) Elements of Fold Style Analysis in the Karbasi Anticline, Interior Fars Region, Zagros. Geosciences, 24, 293-302.

[30] Baratpour, F., Arian, M. and Solgi, A. (2015) Geometric Analysis of Tukak and Kamarun Anticlines on Izeh Zone, Zagros. Geosciences, 24, 191-200.

[31] Gholamhosein Fard, N., Sorbi, A. and Arian, M. (2015) Active Tectonics of Kangavar Area, West Iran. Open Journal of Geology, 5, 422-441.

[32] Maleki, Z., Arian, M. and Solgi, A. (2015) Folding Pattern in the Fars Province, Zagros Folded Belt: Case Study on the Karbasi and Khaftar Anticlines, Interior Fars, Iran. Solid Earth Discussions, 7, 2347-2379. http://dx.doi.org/10.5194/sed-7-2347-2015

[33] Arian, M. and Qorashi, M. (2006) The Movement Potential Evaluation of the Major Quaternary Faults in Alborz-Central Iran Border Zone, from the East of Tehran to the East of Semnan. Journal of Geosciences, 15, 184-188.

[34] Poroohan, N., Poukermani, M. and Arian, M. (2009) An Assessment on Correlations of Seismotectonic Parameters Preceding and Following Roudbar-Manjil Earthquake (Gilan, North of Iran). Australian Journal of Basic \& Applied Sciences, 3, 2643-2652.

[35] Farrokhnia, A.R., Pirasteh, S., Pradhan, B., Pourkermani, M. and Arian, M. (2011) A Recent Scenario of Mass Wasting and Its Impact on the Transportation in Alborz Mountains, Iran Using Geo-Information Technology. Arabian Journal of Geosciences, 4, 1337-1349. http://dx.doi.org/10.1007/s12517-010-0238-7

[36] Arian, M. and Nouri, R. (2015) Lineament Tectonics and Mineralization in Tarom Area, North Iran. Open Journal of Geology, 5, 115-124. http://dx.doi.org/10.4236/ojg.2015.53011

[37] Feizi, F. and Arian, M. (2011) The Role of Structural Controllers in Geneses of Copper Deposits in 1:50000 Map of Saiin Qaleh. Journal of Sciences, 21, 1-10.

[38] Sorbi, A., Arian, M. and Pourkermani, M. (2011) The Application of Geomorphic Indices to the Assessment of Relative Tectonic Activity Levels in Tehran Quadrangle. Journal of the Earth, 6, 1-9.

[39] Arian, M., Toudeshki, V.H. and Noroozpour, H. (2011) Active Tectonics of QezelOzan River Basin, NW Iran. Journal of Applied Environmental and Biological Sciences, 1, 291-295.

[40] Alizadeh, H., Arian, M., Lotfi, M., Ghorashi, M. and Ghorbani, M. (2015) Determination of Porphyry Copper Deposit Locations Using Photo Lineament Factor in Northern Parts of the Dehaj-Sardoiyeh Belt. Geosciences, 24, $247-252$.

[41] Housini Toudeshki, V., Pourkermani, M., Arian, M. and Khosrotehrani, K.H. (2011) Influence of Structures on the GhezelOzan River. Geosciences, 21, 55-60.

[42] Housini Toudeshki, V. and Arian, M. (2011) Morphotectonic Analysis in the GhezelOzan River Basin, NW Iran. Journal of Geography and Geology, 3, 258-260.

[43] Arian, M., Pourkermani, M., Sistanipour, A. and Noroozpour, H. (2011) Kinematic Significance of Fold- and FaultRelated Fracture Systems in the Rafsanjan’s Northeast Highlands (Central Iran). Journal of Basic and Applied Scientific Research, 1, 3398-3406.

[44] Arian, M., Pourkermani, M., Sistanipour, A. and Noroozpour, H. (2011) Seismicity and Fault Segmentation of BafqBaghin Fault System (Central Iran). Journal of Applied Environmental and Biological Sciences, 1, 382-396.

[45] Javadi Mosavi, E., Arian, M., Ghorashi, M. and Nazemi, M. (2012) Measurements of Geomorphic Indices in Tabas Area. Journal of the Earth, 7, 213-225.

[46] Arian, M. (2013) Physiographic-Tectonic Zoning of Iran’s Sedimentary Basins. Open Journal of Geology, 3, 169-177. http://dx.doi.org/10.4236/ojg.2013.33020 